\title{
Erosion index formulation with respect to reservoir life in the upper Citarum watershed
}

\author{
Bakhtiar $^{1, *}$ \\ ${ }^{1}$ Civil Engineering Department, Sangga Buana University, Bandung, Indonesia
}

\begin{abstract}
This study aimed to formulate erosion index in the upper Citarum watershed with respect to the Saguling reservoir life. Soil and Water Assessment Tool model was incorporated to simulate hydrological processes in the catchment. From the calibration and validation results, the model is considerably of good performance. The simulated sediment inflow at Nanjung outlet was then extrapolated to determine the sediment inflow into the reservoir. The study revealed that the average value of sediment inflow into the reservoir is 29.24 tonnes/ha/year just below the tolerable erosion limit of 30 tonnes/ha/year assumed by Hammer (1981). It was also found that the relationship between sediment yield and sediment inflow is non linear. Erosion index is formulated as the ratio between the mean annual sediment yield generated in the watershed and the mean annual sediment yield that leads dead storage to be full in the designated life of the reservoir. Erosion index equals to 1.0 indicates that the dead storage will be full in the designated life of the reservoir. A classification of erosion index can be subsequently be made based on erosion index and reservoir life relationship.
\end{abstract}

\section{Introduction}

The upper Citarum watershed covers the fountain of the Citarum river down to Saguling with an area of 1744.98 $\mathrm{km} 2$ as a part of the Citarum watershed, one of the biggest watershed in West Java. The observed monthly rainfall in 2008 is averaged to be $172 \mathrm{~mm}$ with the total annual rainfall of $2,070 \mathrm{~mm}$. The topography of the region is dominated by mountains along the borders and a broad plain in the middle. The sedimentation rate in the Upper Citarum watershed in the last decade is reported to be increasing. It is indicated by the mean sedimentation rate of $4,048,132$ tonnes per year (PT Indonesia Power [1]). This fact is due to the ecosystem degradation and the decreasing forest area over the watershed and the catchment of the Saguling reservoir. The aim of this study is to analyse the effect of rainfall and land use scenarios on sediment yied in the Upper Citarum watershed.

\section{Method}

In this study the erosion and sedimentation behaviour is modeled using ArcSWAT tool (Arc GIS Interface for SWAT Model). SWAT model (Soil and Water Assessment Tool) is a semidistributed watershed model with ArcGIS interface delineating subbasins and river networks from digital elevation model and calculating the daily water balance from meteorological, soil and land use data.
The erosion modeling in SWAT is based on the following Modified Universal Soil Loss Equation (MUSLE) equation (Neitsch [2]):

$$
\text { sed }=11.8 \cdot\left(Q_{\text {suf }} \cdot Q_{\text {peak }} \cdot \text { area }_{\text {hru }}\right)^{0.56} \cdot K_{\text {USLE }} \cdot C_{\text {USLE }} \cdot P_{\text {USLE }} \cdot L S_{\text {USLE }} \cdot C F R G
$$

where:

sed $=$ sediment yield (tonnes)

$Q_{\text {surf }}=$ surface runoff $(\mathrm{mm} / \mathrm{ha})$

$Q_{\text {peak }}=$ peak runoff rate $\left(\mathrm{m}^{3} / \mathrm{s}\right)$

area $_{h r u}=$ area of the HRU (hydrologic response unit (ha)

$K_{U S L E}=$ USLE soil erodibility factor (0.013 tonnes $\mathrm{m}^{2} \mathrm{hr} /\left[\mathrm{m}^{3}\right.$ tonne $\left.\left.\mathrm{cm}\right]\right)$

$C_{U S L E}=$ USLE cover and management factor

$P_{U S L E}=$ USLE support practice factor

$L S_{U S L E}=$ USLE topographic factor

$C F R G=$ coarse fragment factor

\section{Soil and water assessment tool (SWAT)}

SWAT models chosen for this study given the ability to simulate the processes of land management on a watershed-large watershed. SWAT Model is physically based simulation model (physically based) that was developed to simulate the processes of landscapes and watersheds for continuous time with a high degree of spatial details that allow the watershed was divided into sub-watershed. Each sub-watershed is divided again into some combination of land use and soil type called the hydrologic response unit (HRU) based on the percentage 
threshold used in selecting land use and soil types (Arnold et al. [3]).

\section{Data preparation and analysis}

The data prepared in the simulation process is data in the form of data hidroklimatologi rainfall, evaporation, climate and discharge, as well as physical data of Citarum upstream in the form of topographic maps, land use maps, river networks, the type of soil and sediment there. More detailed analysis and clear of each data will be described in the following. Data input for the model preparation derived from various sources are shown in Table 1 below.

Table 1. Model input data and corresponding data sources.

\begin{tabular}{|c|c|c|c|}
\hline Type of data & Scale & Source & Description \\
\hline $\begin{array}{l}\text { Digital } \\
\text { elevation } \\
\text { model }\end{array}$ & $\begin{array}{c}90 \mathrm{~m} \\
\text { resolution }\end{array}$ & $\begin{array}{c}\text { Shuttle } \\
\text { Radar } \\
\text { Topographic } \\
\text { Mission } \\
\text { (SRTM) }\end{array}$ & $\begin{array}{l}\text { Elevation, } \\
\text { length and } \\
\text { slope }\end{array}$ \\
\hline $\begin{array}{c}\text { River } \\
\text { networks } \\
\text { (hydrography } \\
\text { ) }\end{array}$ & $\begin{array}{c}\text { Projection: } \\
\text { UTM/WG } \\
\text { S84 }\end{array}$ & $\begin{array}{c}\text { West Java } \\
\text { Water } \\
\text { Resources } \\
\text { Agency } \\
\end{array}$ & \\
\hline Geology & Zone $48 \mathrm{~S}$ & $\begin{array}{l}\text { Soil and } \\
\text { Agroclimate } \\
\text { Research } \\
\text { Centre }\end{array}$ & $\begin{array}{c}\text { Soil physical } \\
\text { properties } \\
\text { (bulk density, } \\
\text { texture, } \\
\text { organic } \\
\text { matter, } \\
\text { hydraulic } \\
\text { conductivity, } \\
\text { etc.) }\end{array}$ \\
\hline $\begin{array}{c}\text { Landuse/ } \\
\text { Landcover }\end{array}$ & $1: 250.000$ & $\begin{array}{c}\text { West Java } \\
\text { Spatial } \\
\text { Planning } \\
\text { Agency }\end{array}$ & $\begin{array}{c}\text { Landuse } \\
\text { classification }\end{array}$ \\
\hline Rainfall & $\begin{array}{l}\text { Projection: } \\
\text { UTM/WG } \\
\text { S84 }\end{array}$ & $\begin{array}{l}\text { Saguling } \\
\text { reservoir } \\
\text { authority }\end{array}$ & \\
\hline $\begin{array}{c}\text { Streamflow } \\
\text { and sediment }\end{array}$ & Zone $48 \mathrm{~S}$ & $\begin{array}{l}\text { Saguling } \\
\text { reservoir } \\
\text { authority }\end{array}$ & \\
\hline
\end{tabular}

\section{Model setup}

After all the input data is prepared and added to the SWAT database, SWAT models hereafter devised a new project with ArcSWAT, i.e. SWAT interface and ArcGIS. The main steps of the SWAT procedure include delineating sub-watershed and HRU and writing all input files. Figure 1 below shows the steps SWAT modeling using ArcSWAT (Winchell et al, 2009 [4]).

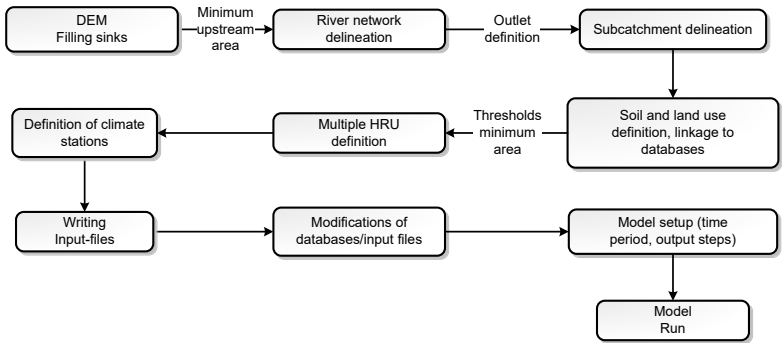

Fig. 1. Steps for setting up a new SWAT project with ArcGIS User Interface.

The first step required to build a model of SWAT is to define parameters related to elevation as: elevation above sea level, slope aspect, network flow, distance to the nearest river, and divide the watershed into sub-subwatershed. DEM data with a resolution of $90 \mathrm{~m}$ were obtained from the Shuttle Radar Topographic Mission (SRTM) is used in this stage.

ArcSWAT automatically delineates the boundaries of the watershed and river network based on DEM data. The number of sub-watershed is determined based on the level of accuracy we have set previously. The higher level of accuracy, the greater the number of subwatershed generated. In this study the number of subwatershed produced are 92 sub-watersheds (see Figure 2).

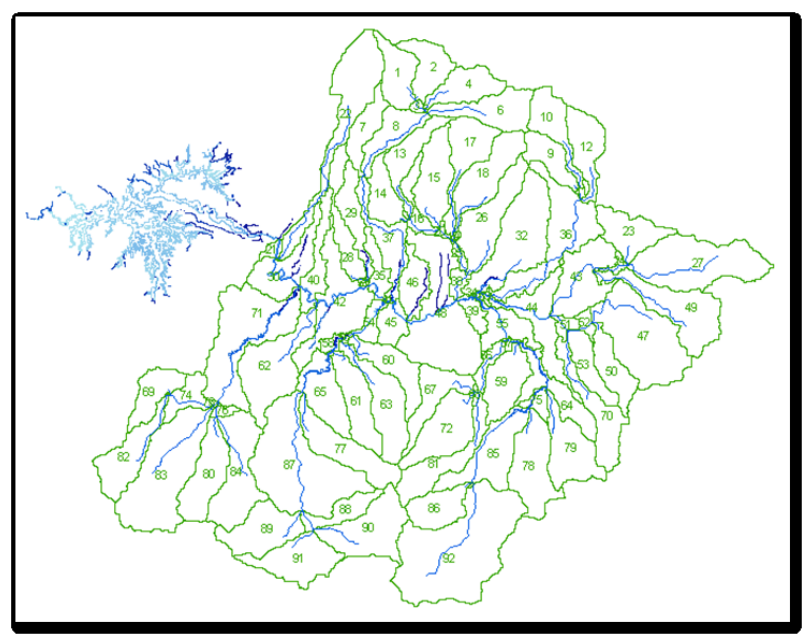

Fig. 2. Watershed delineation using ArcSWAT.

\section{Model calibration}

Calibration was perfomed on water yield, average annual water inflow, and annual sediment inflow at the watershed outlet i.e. Nanjung gauge station (see Figure 3) for the period of 11 years i.e from 1987 to 1997 . The model performance is then evaluated on their statistical parameters i.e. coefficient of correlation (r), coefficient of determination (R2), model efficiency (ME), and index of agreement (IA) (Spiegel, 1961). Table 2 shows the observed and simulated mean annual values as well as their respective model performance. 


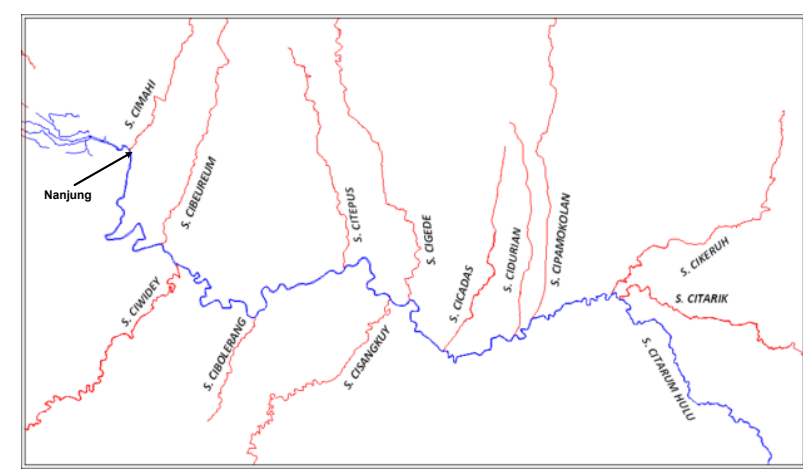

Fig. 3. Location of Nanjung gauging station.

Table 2. Summary of the calibrated annual values.

\begin{tabular}{|c|c|c|c|}
\hline Parameter & $\begin{array}{c}\text { Water } \\
\text { yield }\end{array}$ & $\begin{array}{c}\text { Water } \\
\text { inflow }\end{array}$ & $\begin{array}{c}\text { Sediment } \\
\text { inflow }\end{array}$ \\
\hline Unit & $\mathrm{mm}$ & $\mathrm{m}^{3} / \mathrm{s}$ & tonnes \\
\hline Observed & 1,503 & 82.77 & $3,862,941$ \\
\hline Simulated & 1,513 & 83.57 & $3,678,091$ \\
\hline $\boldsymbol{r}$ & 0.938 & 0.941 & 0.668 \\
\hline $\boldsymbol{R}^{2}$ & 0.876 & 0.886 & -0.497 \\
\hline $\boldsymbol{M} \boldsymbol{E}$ & 0.874 & 0.878 & -0.497 \\
\hline $\boldsymbol{I} \boldsymbol{A}$ & 0.968 & 0.969 & 0.755 \\
\hline
\end{tabular}

\section{Model validation}

Validation was perfomed on the calibrated model using the consecutive 11 year data i.e. from 1998 to 2008. Based on the validation on the annual observed values, it can be seen that the model is considerably of good performance as shown by the coefficient of correlation, coefficient of determination, model efficiency and index of agreement which are close to 1 except for the sediment inflow for the same reason as the case of sediment inflow calibration.

Table 3. Summary of the validated annual values.

\begin{tabular}{|c|c|c|c|}
\hline Parameter & $\begin{array}{c}\text { Water } \\
\text { yield }\end{array}$ & $\begin{array}{c}\text { Water } \\
\text { inflow }\end{array}$ & $\begin{array}{c}\text { Sediment } \\
\text { inflow }\end{array}$ \\
\hline Unit & $\mathrm{mm}$ & $\mathrm{m}^{3} / \mathrm{s}$ & tonnes \\
\hline Observed & 1,628 & 89.61 & $5,668,783$ \\
\hline Simulated & 1,626 & 89.74 & $5,328,818$ \\
\hline $\boldsymbol{r}$ & 0.987 & 0.988 & 0.742 \\
\hline $\boldsymbol{R}^{2}$ & 0.974 & 0.975 & -70.500 \\
\hline $\boldsymbol{M} \boldsymbol{E}$ & 0.974 & 0.976 & -70.565 \\
\hline $\boldsymbol{I} \boldsymbol{A}$ & 0.993 & 0.994 & 0.272 \\
\hline
\end{tabular}

\section{Determination of sediment inflow into the reservoir}

Since the inflow of sediment being modeled by SWAT only to outlets Citarum upstream, ie heading suspect water Nanjung, then the data volume of sediment observations from Saguling to be used for calibration and validation of models must be transformed into data inflow of sediment at Nanjung assuming a volume of sediment proportional of the watershed area as follows:

$$
\operatorname{sed}_{\text {out }(\text { obs })}^{*}=\frac{A_{D A S}}{A_{D T W}} \cdot V_{\text {sed }} \cdot \gamma_{\text {sed }}
$$

where:

$$
\begin{aligned}
\text { sed }_{\text {out }(\text { obs })}{ }^{*}= & \begin{array}{l}
\text { observed sediment inflow at Nanjung } \\
\text { (tonnes/year) }
\end{array} \\
A_{D A S}= & \text { area of the watershed upstream of Nanjung } \\
& =1,745 \mathrm{~km}^{2} \\
A_{D T W}= & \text { area of Saguling catchment }=2,313 \mathrm{~km}^{2} \\
V_{\text {sed }}= & \text { observed annual sediment entering the } \\
& \text { reservoir }\left(\mathrm{m}^{3}\right) \\
\gamma_{\text {sed }}= & \text { initial specific gravity of sediment }=1,229 \\
& \text { tonnes } / \mathrm{m}^{3}
\end{aligned}
$$

The sediment inflow into the reservoir is obtained from the inflow of sediments in the watershed outlet resulted from the simulation model SWAT (sedout*) using the following equation:

$$
\operatorname{sed}_{\text {out }(\text { sim })}=\frac{A_{D T W}}{A_{D A S}} \cdot \operatorname{sed}_{\text {out }(\text { sim })}^{*}
$$

where:

$\operatorname{sed}_{\text {out }(\text { sim })}=$ simulated sediment inflow into the reservoir (tonnes/year)

$A_{D A S} \quad=$ area of the watershed upstream of Nanjung $=1,745 \mathrm{~km}^{2}$

$A_{D T W}=$ area of Saguling catchment $=2,313 \mathrm{~km}^{2}$

$\operatorname{sed}_{\text {out(sim) }}{ }^{*}=$ simulated sediment inflow at the catchment outlet (tonnes/year)

The simulated sediment inflow at Nanjung obtained from the SWAT model simulation is then used to determine the sediment inflow into the Saguling reservoir using Equation 3. It is found that the average value of sediment inflow into the reservoir is 29.24 tonnes/ha/year which is close to the tolerable erosion limit of 30 tonnes/ha/year assumed by Hammer (1981) in Arsyad [5].

\section{Relationship between sediment yield and sediment inflow}

The simulated sediment yields and sediment inflows are tabulated in the following table.

Table 4. Relationship between sediment yield and sediment inflow.

\begin{tabular}{|c|c|c|c|}
\hline $\begin{array}{c}\text { Rainfall } \\
(\boldsymbol{R})\end{array}$ & $\begin{array}{c}\text { Sediment } \\
\text { yield } \\
(\text { Sed })\end{array}$ & $\begin{array}{c}\text { Water } \\
\text { inflow } \\
\left(\boldsymbol{I}_{\boldsymbol{w}}\right)\end{array}$ & $\begin{array}{c}\text { Sediment } \\
\text { inflow } \\
\left(\text { Sed }_{\text {out }}\right)\end{array}$ \\
\hline 1,021 & 165.90 & $1,750,878,720$ & $3,256,757$ \\
\hline 1,062 & 170.66 & $1,841,387,040$ & $3,112,277$ \\
\hline 1,174 & 197.45 & $2,020,196,160$ & $3,319,056$ \\
\hline 1,236 & 210.23 & $2,140,663,680$ & $3,808,166$ \\
\hline 1,359 & 202.14 & $2,440,255,680$ & $4,514,658$ \\
\hline 1,403 & 213.64 & $2,521,618,560$ & $4,444,406$ \\
\hline 1,423 & 247.35 & $2,364,569,280$ & $4,641,906$ \\
\hline 1,452 & 177.75 & $2,586,582,720$ & $4,481,520$ \\
\hline 1,494 & 201.44 & $2,476,206,720$ & $4,575,631$ \\
\hline 1,507 & 257.19 & $2,626,633,440$ & $5,328,516$ \\
\hline 1,510 & 214.64 & $2,630,733,120$ & $4,702,879$ \\
\hline
\end{tabular}


Based on Table 4 above, the relationship between sediment yield and sediment inflow can be formulated as:

$$
\text { Sed }_{\text {out }}=20.394 \operatorname{Sed}^{1,009}
$$

where:

$\operatorname{Sed}_{\text {out }}=$ mean annual sediment inflow (tonnes/year)

Sed = mean annual sediment yield (tonnes/ ha/year)

\section{Determination of reservoir life}

Reservoir life can be predicted by the trap efficiency method. Gunner Brune (1953 in the Bureau of Reclamation [6]) suggests that the trap efficiency depends on the ratio between the reservoir storage capacity $(C)$ and the annual water inflow $\left(I_{w}\right)$. The trap efficiency of a reservoir reduces with time since the capacity of the reservoir is reduced by the accumulated sediment. To determine the trap efficiency curve equation median Brune (Bureau of Reclamation [6]) in Figure 4 is used.

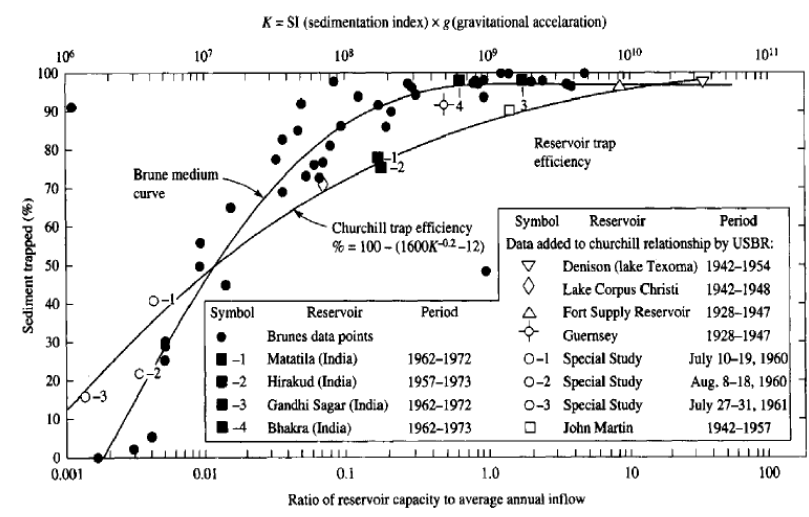

Fig. 4. Trap efficiency curves (Churchill, 1948; Brune, 1953).

The reservoir life is achieved when the volume of the dead storage has been full of sediment that blocks the intake.

For example, according to Table 4 in the previous section a mean annual rainfall of $1,062 \mathrm{~mm}$ results in the sediment yield of 170.66 tonnes/ha, the sediment inflow of 3,112,277 tons/year and the average water inflow of $58.39 \mathrm{~m}^{3} / \mathrm{s}$ which is equal to:

\section{$I_{w}=58.39 \cdot 60 \cdot 60 \cdot 24 \cdot 365=1,841,387,040 \mathrm{~m}^{3} /$ year}

According to data from PT Indonesia Power Service Business Unit Saguling [1] the total capacity of the reservoir is 875 million $\mathrm{m}^{3}$ with a 167.689 million $\mathrm{m}^{3}$ dead storage. Assuming that the sediment in the reservoir is located in a continuously submerged zone and consists of $15 \%$ clay, $35 \%$ silt and $50 \%$ sand, then using Equation (5) the initial specific gravity of sediment can be determined as follows:

$$
\gamma_{\text {sed }}=\gamma_{c} p_{c}+\gamma_{m} p_{m}+\gamma_{s} p_{s}
$$

where:

$\gamma_{\text {sed }}=$ specific gravity of sediment (tonnes $/ \mathrm{m}^{3}$ )

$p_{c}=$ percentage of clay $=15 \%$

$p_{m}=$ percentage of silt $=35 \%$ $p_{s}=$ percentage of sand $=50 \%$

$\gamma_{c}=$ specific gravity of clay $=0.416$ tonnes $/ \mathrm{m}^{3}$

$\gamma_{m}=$ specific gravity of silt $=1.120$ tonnes $/ \mathrm{m}^{3}$

$\gamma_{s}=$ specific gravity of sand $=1.550$ tonnes $/ \mathrm{m}^{3}$

Hence:

$\gamma_{\text {sed }}=0.416 \cdot 0.15+1.120 \cdot 0.35+1.550 \cdot 0.50=1.229$ tonnes $/ \mathrm{m}^{3}$

Furthermore, the average specific gravity of sediment after $t$ years of reservoir operation can be determined using the following equation:

$$
\gamma_{\text {sed }, t}=\gamma_{\text {sed,o }}+0.4343 \cdot K\left[\frac{t}{t-1}(\ln t)-1\right]
$$

where:

$\gamma_{\text {sed, } t}=$ average specific gravity of sediment after $t$ years of reservoir operation

$\gamma_{\text {sed,o }}=$ initial specific gravity of sediment $=1.229$ tonnes $/ \mathrm{m}^{3}$ (from the previous calculation)

$K=$ constant which is based on the type of reservoir operation and sediment size analysis obtained by the following equation:

$$
K=K_{c} \cdot p_{c}+K_{m} \cdot p_{m}+K_{s} \cdot p_{s}
$$

where:

$K_{c}=$ constant for clay $=0.256$ tonnes $/ \mathrm{m}^{3}$

$K_{m}=$ constant for silt $=0.091$ tonnes $/ \mathrm{m}^{3}$

$K_{s}=$ constant for sand $=0$

Hence:

$K=0.256 \cdot 0.15+0.091 \cdot 0.35+0 \cdot 0.50=0.070$ tons $/ \mathrm{m}^{3}$

Entering $\gamma_{\text {sed,o }}=1,229$ tonnes $/ \mathrm{m}^{3}$ and $\mathrm{K}=0.070$ tonnes $/ \mathrm{m}^{3}$ into Equation (6), the average specific gravity of sediment after $t$ years of reservoir operation can be determined as follows:

$$
\gamma_{\text {sed }, t}=1.229+0.4343 \cdot 0.070\left[\frac{t}{t-1}(\ln t)-1\right]
$$

Reservoir life can subsequently be determined implicitly using the following equation:

$$
D E A D_{t=n}=\overline{s e d}_{\text {out }} \sum_{t=1}^{t=n} \frac{0,96^{-0,25 \log \left(\frac{C_{o}-D E A D_{t-1}}{I_{w}}\right)}}{\gamma_{\text {sed }}}
$$

where:

$D E A D_{t=n}=$ specific gravity of sediment (tonnes $\left./ \mathrm{m}^{3}\right)$

The reservoir life can eventually be determined implicitly using Equation (9). By interpolation the reservoir life is predicted to be 70.49 years.

\section{Erosion index}

Erosion index is a function of sediment yield and reservoir life. Sediment yield generated by the SWAT model simulation is the total sediment that consists of bed load and suspended load. Reservoir sedimentation is only influenced by suspended load and not affected by 
bed load. It is for this reason, the correlation between reservoir life and sediment yield becomes less significant as compared to the effect of sediment inflow in the dead storage. This is proved by the evidence that the value of the coefficient of correlation ( $r$ ) is -0.80 which is far from 1.0. The relationship between sediment yield and reservoir life is shown in Figure 5 below.

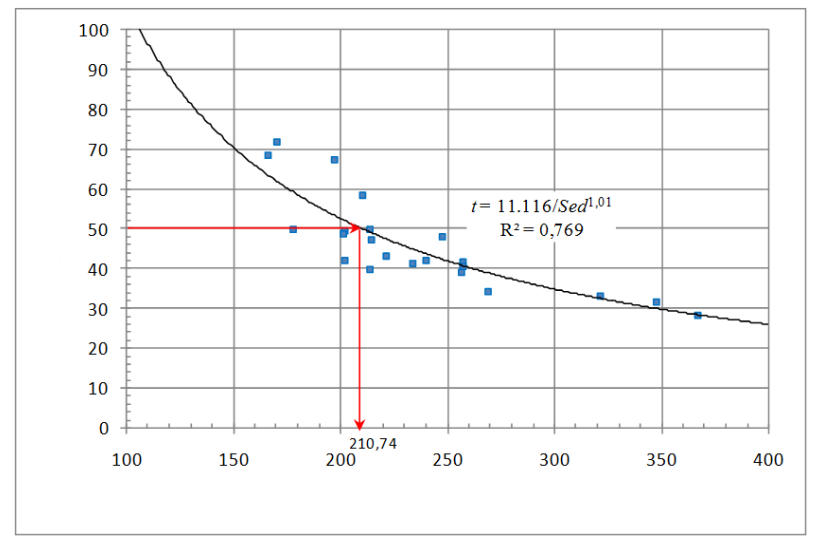

Fig. 5. Relationship between sediment yield and reservoir life.

Erosion index (IE) is formulated as the ratio between the mean annual sediment yield generated in the watershed $(\mathrm{Sed})$ and the mean annual sediment yield that leads dead storage to be full in the designated life of the reservoir $\left(\mathrm{Sed}_{t}\right)$. Erosion index equal to 1.0 indicates that the dead storage will be full in the designated life of the reservoir. In this study the designated life of the reservoir $(u)$ is set to be 50 years. Thus, in this case, erosion index equal to 1.0 refers to the sediment yield that causes the dead storage to be full in the period of 50 years.

Hence, for this case, erosion index $(I E)$ is formulated as the ratio between the mean annual sediment yield that takes place in the watershed $(\mathrm{Sed})$ and the mean annual sedimen yield that causes the dead storage to be full in the period of 50 years $\left(\operatorname{Sed}_{50}\right)$.

According to the curve in Figure 5 above, the reservoir life $(u)$ of 50 years is correlated with the sediment yield of 210.74 tonnes/ha/year. Therefore, erosion index can be formulated as:

$$
I E=\frac{S e d}{\operatorname{Sed}_{u}}=\frac{S e d}{\operatorname{Sed}_{50}}=\frac{S e d}{210.74}
$$

where:

$$
\begin{aligned}
& I E \quad=\text { erosion index } \\
& \text { Sed }=\text { actual mean annual sediment yield } \\
& \text { (tonnes/ha/year) } \\
& \operatorname{Sed}_{u}=\text { mean annual sediment yield that leads dead }
\end{aligned}
$$

Erosion index values for various sediment yield are shown in Figure 6.

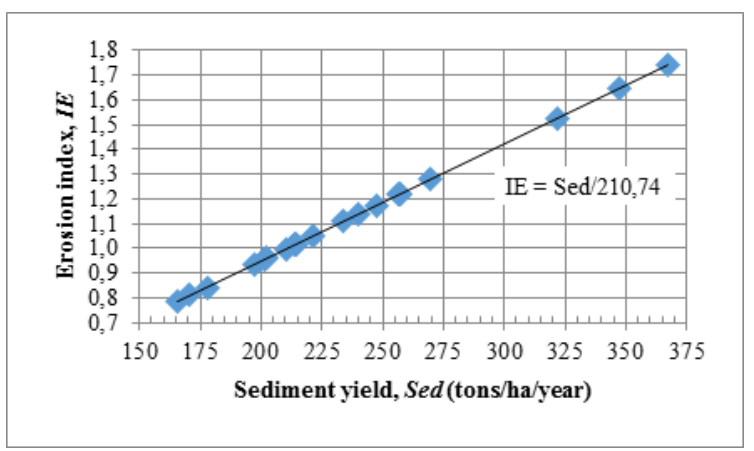

Fig. 6. Erosion index determination based on sediment yield and reservoir life.

The relationship between erosion index and reservoir life is shown in Figure 7.

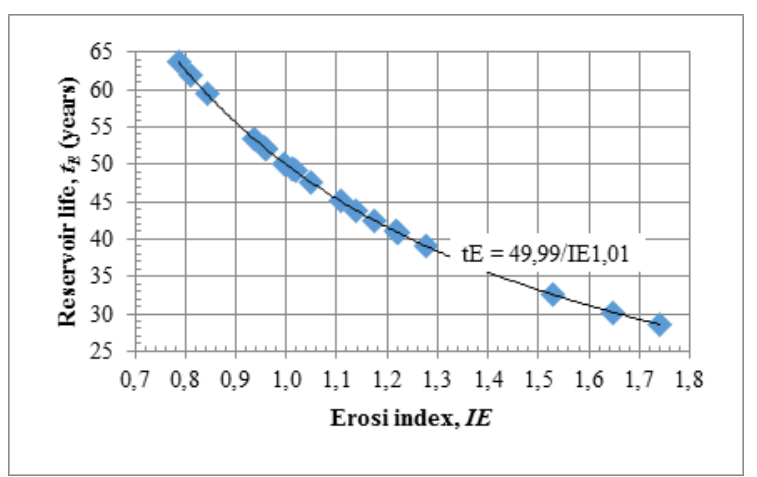

Fig. 7. Relationship between erosion index and reservoir life.

Based on the relationship between erosion index and reservoir life above, a classification of erosion index can be made as shown in Table 5 below.

Table 5. Erosion index classification.

\begin{tabular}{|c|c|c|c|}
\hline $\begin{array}{c}\text { Sediment } \\
\text { yield, } \boldsymbol{S e d} \\
\text { (tonnes/ha/year) }\end{array}$ & $\begin{array}{c}\text { Erosion } \\
\text { index, } \\
\boldsymbol{I E}\end{array}$ & Category & $\begin{array}{c}\text { Reservoir } \\
\text { life, } \boldsymbol{t}_{\boldsymbol{E}} \\
\text { (years) }\end{array}$ \\
\hline Sed $<210,74$ & $I E<1$ & Non critical & $t_{E}>50$ \\
\hline$S e d=210,74$ & $I E=1$ & Critical & $t_{E}=50$ \\
\hline$S e d>210,74$ & $I E>1$ & Very critical & $t_{E}<50$ \\
\hline
\end{tabular}

\section{Comparison between erosion index and erosion hazard index}

If the values of erosion index found in this study are compared to the values of erosion hazard index (Hammer, 1981 in Arsyad [5]), the same sediment yield will fall into a different category (see Table 6). The difference resulted because each index has different ranges for their respective categories.

Table 6. Erosion hazard index (IBE) assessment criteria.

\begin{tabular}{|c|c|}
\hline Erosion hazard index (IBE) & Category \\
\hline $\mathrm{IBE} \leq 1.0$ & Low \\
\hline $1.0<\mathrm{IBE} \leq 4.0$ & Moderate \\
\hline $4.0<\mathrm{IBE} \leq 10.0$ & High \\
\hline $\mathrm{IBE}>10.0$ & Very high \\
\hline
\end{tabular}


The comparison between erosion index and erosion hazard index is shown in Figure 8.

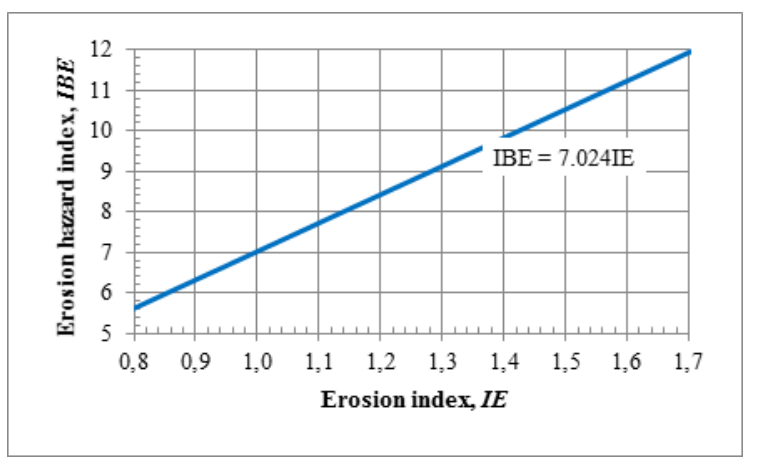

Fig. 8. Relationship between erosion index and reservoir life.

\section{Conclusion}

From the previous discussion it can be concluded that:

1. The mean sediment inflow into Saguling reservoir is 29.24 tonnes/ha/ year which is close to the tolerable erosion rate of 30 tonnes/ha/year (Hammer, 1981).

2. The relationship between sediment yield and sediment inflow is nonlinear with an exponential equation.

3. Erosion index (IE) is formulated as the ratio between the mean annual sediment yield generated in the watershed (Sed) and the mean annual sediment yield that leads dead storage to be full in the designated life of the reservoir (Sedt).

4. Based on the relationship between erosion index and reservoir life, erosion index can be classified into three categories i.e. non critical, critical and very critical.

5. If the values of erosion index found in this study are compared to the values of erosion hazard index, the same sediment yield will fall into a different category. The difference resulted because each index has different ranges for their respective categories.

\section{Recommendation}

Based on this study it is recommended that:

1. Regarding a great number of parameters involved in the modelling process, it is recommended to conduct further research on those parameters to obtain the appropriate values in order to obtain acceptable results.

2. In Indonesia modelling using SWAT model is a new thing and scarce. It is for this reason, the implementation of SWAT model into the future research will be very much welcomed.

3. The above resulted formula are only valid for the location under consideration. However, the methods can be applied to produce a similar formula for other locations.

\section{References}

1. The Saguling Service Business Unit, Monitoring Report of The Saguling Reservoir Sedimentation (2008)

2. S. Neitsch, J. Arnold, J. Kiniry, J. Williams, Soil and Water Assessment Tool: Theoretical Documentation Version 2005, 225 (2005)

3. J. G. Arnold, R. Srinivasan, R. S. Muttiah, J. R. Williams, Large Area Hydrologic Modeling and Assessment Part I: Model Development, Journal of the American Water Resources Association, 34(1), 73-89 (1998)

4. M. Winchell, R. Srinivasan, J.M. Di Luzio, ArcSWAT 2.3.4 Interface for SWAT2005: User's Guide (2009)

5. S. Arsyad, Konservasi Tanah dan Air (1989)

6. Bureau of Reclamation, Erosion and Sedimentation Manual (2006) 